\title{
Current Status and Development trend of AIC (Agro-industrial Complex) in the Republic of Kazakhstan
}

\author{
Sandugash Tokenova \\ 010000, Sh.Kudayberdyuly Street 25/1, Apt 320, KATU named after S. Seifullin \\ sandugash_tokenova@mail.ru
}

\section{Doi:10.5901/mjss.2016.v7n2p137}

\begin{abstract}
At the present stage the competitiveness of small businesses agribusiness depends primarily on their ability to integrate into the supply chains. To provide this capability, all elements of the management system of small businesses must meet the standards of corporate governance larger agricultural enterprises, included in the supply chains. Before administering the owners, a small business gets the implementation task at the enterprise integrated management system, consisting the elements of a balanced scorecard, security products, quality management systems, etc. This system should be, on the one hand, convenient and understandable for managers of large agricultural enterprises - small businesses partners on the supply chain. On the other hand, the system should be available for small business owners control - does not require significant expenditures for its implementation and specific competencies members. In our opinion, in order to develop such an integrated management system to meet these very contradictory requirements, refer to the management accounting concept
\end{abstract}

Keywords: Production, import, partners, dairy products, poultry, meat, management accounting

\section{Introduction}

Support of stable and profitable operation in a broadening and deepening of market relations is important for the small agricultural enterprises. Means of achieving effective financial and economic activity of AIC is implementation of package plan aimed at management improvement, increase of agricultural production's efficiency, the growth of labor productivity, the automation of information support of management decision-making.

Underestimation of management accounting role leads to inefficient use of material, labor, intellectual, organizational, informational, and financial resources of the enterprise, unreasonably adds to the expenses, which leads to higher production costs and lower competitiveness .Analysis of financial and economic activities of agricultural enterprises showed that few of them have a developed management accounting system, which allows to provide need of enterprise's managers with essential information. The lack of systemic researches and lessons learned in the field of organization's effectivization and administrative account functioning at the enterprises of agro-industrial complex leads to losses and reduce the impact of financial and economic activity.

\section{The Up-to-date Positive Dynamics of the Situation of AIC}

In recent years, the production volume of AIC has positive dynamics- in comparison with the previous indicators, and not for example with 1990, production level of agricultural products are not reached until now.

The transition to a market economy in Kazakhstan sharply reduced agricultural production. Productivity indicators in all areas of agriculture, which mainly reside in small commodity farms and inferior to international indicators in several times. Branches possess inherent characteristics such as a low genetic potential and low productivity, lack of modern technology to ensure the necessary volume and quality of products. About $80 \%$ of its agricultural production is realized in the form of raw material without processing, and finished products have weak competitiveness due to the technological backwardness of the processing enterprises.

Primitive production cycles dominate in the processing industry of AIC. In the structure of the production sector, whose share in GDP fell by more than half in comparison with 1990, $71 \%$ comes from the production of flour and bakery products, $11 \%$ to produce beverages and all other types of food products accounts for only 18\% (Sakhanova ,2012).

Capacity factor in the processing industry of AIC is low and ranges from $25 \%$ in the dairy industry to $60 \%$ - in canned vegetables. Among the main problems of the processing industry of AIC are raw material insecurity, the lack of 
serious investment in the industry, chronic current capital's shortage, high interest rate on credit, lack of competitiveness of products in price and quality in comparison with foreign analogs (The Prime minister's edict of the Republic of Kazakhstan of December 7,2012 "About the approval of the plan of measures on support and development of agricultural production processing and food industry").

Figure 1 shows the ratio of imports and domestic production of vegetables in the Republic of Kazakhstan in 2014.

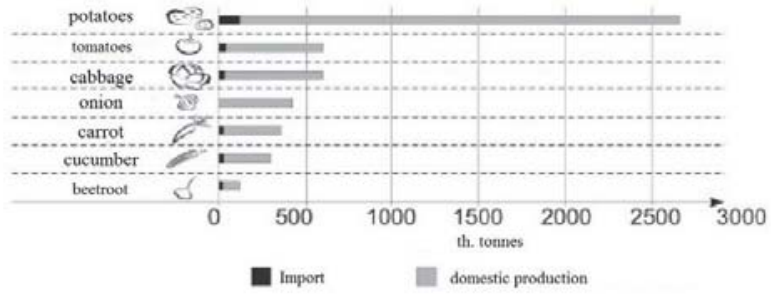

Figure 1. Import and domestic production of vegetables in Kazakhstan at the end of 2014 [The RK Statistics Agency].

In the last five years the quantity of imports of fruits in Kazakhstan grew in 7 times, which indicate a dynamic increase in demand of the population from this country for the fruits and the lack of preparation of local gardeners to satisfy this demand. Consumption of fruit and berry production combines to 8.6 kilograms of stone fruits per year, 1.7 kilograms and 3.1 kilograms of grape berries per head [Agalakova O. , 2008].

The main trade partner of Kazakhstan is China, which supplies almost half of all fruits in this country. Further, among the leading suppliers are Ecuador, Poland, Pakistan, South Africa, Argentina, Turkey and Spain. Uzbekistan takes only the $14^{\text {th }}$ place in the rating of the largest suppliers, which indicates a large number of unaccounted supplies in the statistics from this country. The percentage of imported fruits should be highlighted: apples - $67 \%$ of import from China (for 9 months), apricots - Kyrgyzstan (68\%), peaches - China (40\%) and Kyrgyzstan (40\%). As for vegetables, they are imported, mainly from Russia (cabbage, potatoes), Kyrgyzstan (carrots), Uzbekistan (pepper, eggplants, cucumbers) and China (cucumbers, tomatoes, and potatoes). In the first quarter of 2011, Kazakhstan dramatically increased the supply of vegetables from China.

Since January till March of this year, export of vegetables from Xinjiang Uygur Autonomous Region (North- West China) reached 6 th. 655 tones and its price are $\$ 11.9$ million. Both numbers turned out to be $48,7 \%$ and 2,8 times more in comparison with the last year's level within the analogous period.

Fruit and vegetable production is planned to increase to 540 th. tonnes by 2015 year. Such production volume will almost completely help to replace import in the country. Almaty, Zhambyl, South Kazakhstan and Pavlodar regions remain the most perspective regions for the development of horticulture.

The main volume of meat production is focused in Almaty region - 263 th. tonnes. Next comes Kostanay - 238 th.tonnes, followed by East Kazakhstan region with the volume of 197 th. tonnes. Less productive areas turned out to be: Mangistau, Kyzylorda, Atyrau regions (see fig. 2.)

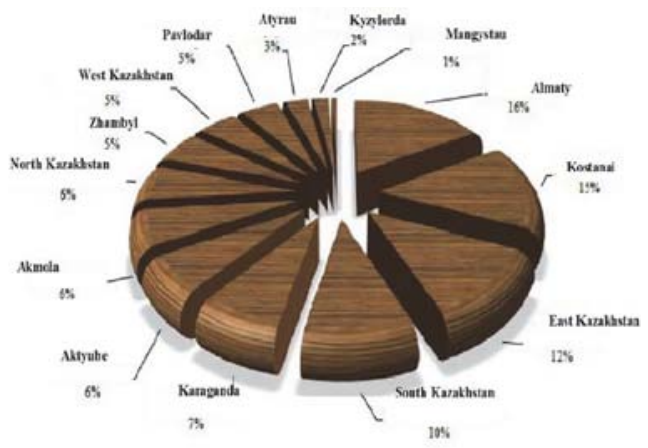

Figure 2. - Meat production in regions of Kazakhstan [The development program of agro-industrial complex in the Republic of Kazakhstan 2013-2020, 2012]. 
Once the Customs Union started to operate, the system of industrial slaughter in Kazakhstan completely failed.

Counters and meat-packing plants were filled with meat from Belarus and Russia. Meat from abroad comes in briquettes, it is cheaper than ours. As a result all sausage department and the enterprises for steel processing began to work with it directly. We tried to negotiate with processors to supply them with our meat at less cost. But they refused, citing to the fact that it is easier to work with meat which comes without bones [Goray,2013].

Poultry industry of the republic is presented by 38 operating poultry farms from which 26 - the enterprises focused on egg production, and 12 - make broiler meat. The base of meat and egg poultry industry is concentrated in 11 areas of the republic; five of them are leaders of the branch - Almaty, South Kazakhstan, Akmola, Karaganda and East Kazakhstan regions [Amalbekova G. E.,2009].

Visually distribution of industrial capacities of fowl production without regard to house farms between regions looks as follows.

Poultry branch is one of the main consumers of compound feed, expenses of which are in excess of $65 \%$ in the cost of eggs and dietary meat. Balanced feeding of a bird at the modern level has to provide an output of 290-310 eggs per year and live weight of young stock in 7 weeks more than $2 \mathrm{~kg}$ with a compound feed consumption, correspondingly $140 \mathrm{~g}$ by $1 \mathrm{egg}$ and $2 \mathrm{~kg}$ by $1 \mathrm{~kg}$ of an additional weight. For a variety of reasons, purchased and farm produced fodder doesn't provide cost minimization of poultry products manufacturing at its peak output. So, the pre-slaughter weight of a broiler is 1,2-1,8 $\mathrm{kg}$ with a compound feed consumption of 2,7-4,3 $\mathrm{kg}$ by $1 \mathrm{~kg}$ of an additional weight. Underbalance and compound feed homogeneity in the feeding of a bird lead to loss to $20 \%$ of gross receipts of eggs; decrease to $30-35 \%$ of meat output.

In recent years, many poultry farms go to the own all-in-one feed production. Formation of fodder base depends on many internal and external factors for each poultry farm: the distance to the nearest feed-milling plant and forwarding charges for transportation of compound feed; availability of own proper feed-processing building and capacity to produce high quality of all-in-one feed; own proper raw material resources etc.

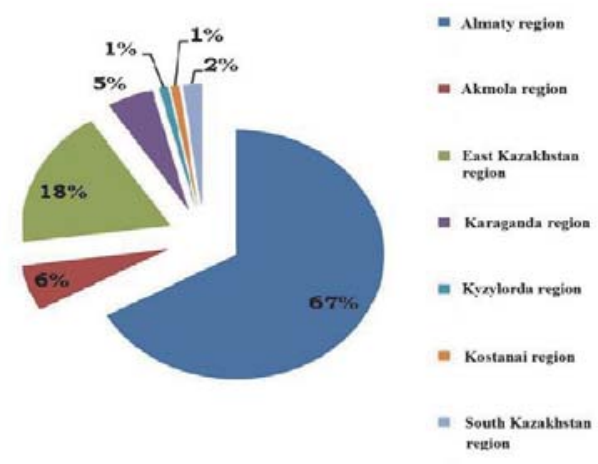

Figure 3. Industrial capacities' distribution of poultry meat production between regions (without regard to privet farms)[ The RK Statistics Agency].

The market of milk has seasonal nature. Its main production falls on spring and summer and early autumn time. In the summer the growth trend of milk production is more noticeable at the expense of increase in a milk yield.

Figure 4 shows the dynamics of milk production in the republic.

The dairy branch of the Republic of Kazakhstan is presented by the agricultural organizations, country farms, farms of the population and the overworking enterprises.

Annually, the livestock of cows increases more than $2,7 \%$ in all categories of farms in the republic, thus in agricultural formations - by $10,7 \%$ and in farms of the population - by $1,4 \%$.

The number of cows as of 01.01.2014 amounts to: 2,683.8 ths. head of cattle in all categories of farms; in agricultural enterprises - 104,5 ths. heads; in country farms-271,3 ths. heads of cattle; in farms of the population-2308,0 ths. heads, that is $86 \%$ of the general livestock. 


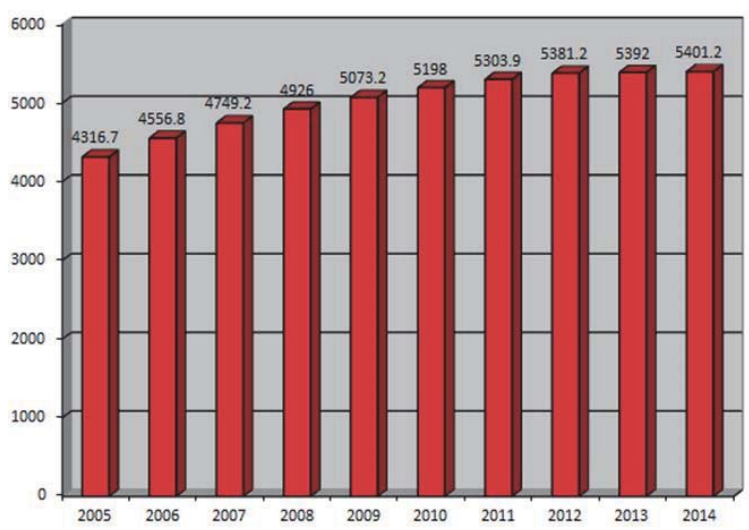

Figure 4. Dynamics of milk production in Kazakhstan (ths. tonnes) [The RK Statistics Agency]. Source:

In present conditions one of the factors of an insufficient further development trend of animal husbandry and growth of cattle's efficiency is the weak food supply.

The largest supplier of dairy products to Kazakhstan is Russia, which supply $86 \%$ of dairy products, $59,6 \%$ of condensed milk, $34,2 \%$ of cheese. Ukraine takes the second place in volume of supplies; Belarus is on the third place. Thus, main suppliers are the CIS countries which work according to the international standards and turn out the products familiar to the population of Kazakhstan [Analysis of an internal situation in the market of dairy products in Kazakhstan. Milk processing. Release. 2011.No 2].

Solution of the problem with growth of quality and competitiveness of dairy raw materials in the republic requires to solve several tasks: improvement of dairy cattle's selection and increase in its efficiency and biological value; use of advanced methods of receiving and initial processing of dairy raw materials; efficiency of raw materials' quality control in receiving and initial processing on the dairy commodity's farms [Linnik ,2011].Accomplishment of these tasks are impossible in modern conditions, when $91 \%$ of milk are produced in privet farmsteads, therefore it is necessary to form specialized dairy farms of large and average sizes in dairy raw zone. A package of measures, providing high quality of raw materials should be carried out only in these zones [Kurmangaliyeva ,2009].

The enterprises of the branch can't completely satisfy the demand and fill the dairy market of Kazakhstan which is called "import-dependent" by the experts (Oil and cheese deficiency in Kazakhstan. Interview with V. Kozhevnikov the executive director of the Dairy union of Kazakhstan).

\section{Results}

Management accounting develops at a fast rate in Kazakhstan when technologies, methods, tools adapt in a few years, which are made in the conditions of developed economies during decades.

According to the opinions of Kazakhstan experts, it is possible to emphasize the following reasons of management accounting's lag in RK:

- director's misunderstanding of the need in usage of modern methods, tools and technologies of management.

- lack of the qualified administrative staff, which can operate the company and develop it on the basis of new methods, tools and technologies of management;

- many enterprises have a lack of orientation to strategic conduct of business;

- lack of the educational environment - dominates on training of specialists in the field of business accounting and audit.

As a rule, for today management accounting takes root into activity of large industrial and manufacturing enterprises and corporations in Kazakhstan. Small and medium-sized enterprises of these branches use system's fragments (separate elements) of management accounting. 


\section{Conclusion}

Incomplete information about indoor and outdoor environment current status of the agricultural organization is one of the major internal uncertainty factors in the solution of administrative tasks, the development prospects of the agricultural enterprise. That is a consequence of the inefficient information organization of management support. For the correct management of the agricultural organization, it is necessary to have an effective system of information support which will provide the satisfaction of productive and financial processes, including planning functions, management and the analysis.

Thus, qualitative and just-in-time information is necessary for effective management of logistic system in the agricultural organization which will help to reveal the quantity of commodity stocks or to define the number of the order in time, the control of the products movement and integration separately working parts of information system. Information is necessary if we endeavor to reduce quantity of commodity stocks or to define the number of orders.

\section{References}

Agalakova O.(2008). S. Increase of retail enterprises competitiveness. Dissertation on competition of Ph.Ds degree, Kirov, p.48.

Amalbekova G. E.(2009). Development of poultry products manufacturing on the basis of an innovation and increase of its competitiveness ,Almaty, p.164.

Analysis of an internal situation in the market of dairy products in Kazakhstan // Milk processing. Release.2011.No 2.

Goray O.(2013), The System of industrial butchering in Kazakhstan didn't justifyitself.[Online] Available: http://www.liter.kz/

Kurmangaliyeva D.B. (2009). Business mechanism of regional market's functioning of dairy products / International scientifically practical conference, Taraz, pp. 29-34.

Linnik A. (2011), The dairy market in Kazakhstan. Interview with the CEO "Tetra Pak

CentralAsia" [Online] Available: http://www.upakovano.ru/interviews/397(June 30, 2011)

Oil and cheese deficiency in Kazakhstan. Interview with V. Kozhevnikov the executive director of the Dairy union of Kazakhstan /I Business portal in Kazakhstan.2011. [Online] Available: http://www.com.kz/v-kazaxstane-deficit-masla-i-syra/

Sakhanova G. B.2012 Development of economic competitiveness of R K: problems and prospects ( as an example of the food industry) Dissertation PhD. Almaty, p.167.

The development program of agro-industrial complex in the Republic of Kazakhstan 2013-2020 (Agrobusiness - 2020) Astana, 2012 $97 \mathrm{p}$.

The Prime minister's edict of the Republic of Kazakhstan of December 7,2012 "About the approval of the plan of measures on support and development of agricultural production processing and food industry".[Online] Available: http://adilet.zan.kz/rus/docs/R 1200000226

The RK Statistics Agency. [Online] Available: http://stat.gov.kz/ 